\title{
Opinions of Final Year and Interns about the EducationalEnviroment and Medical Curriculum At Jazan University
}

\author{
MuslehHussainM Mubarki ${ }^{1}$, Ali Mohammed A Abutaleb ${ }^{1}$, OtaifWaelAli $\mathrm{M}^{1}$, \\ Albaraa Hassan Ali Sahli ${ }^{1}$, Miftah Mohammed Omar A ${ }^{1}$, \\ Mohammad Ali A Dighriri ${ }^{1}$ \\ ${ }^{1}$ Graduated Internes, College Of Medicine, Jazan University, JAZAN, KSA
}

\begin{abstract}
Aim of this study: This study was aimed to assess the opinions of $6^{\text {th }}$ years and interns subjects about the learning and program experience at College of Medicine, Jazan University (CMJU) .

Subjects and methods: A total number of 66 (41 males, 26 females) subjects were involved in this study. The study was based on the quality of the Program Experience Survey, which is a part of a NCAAA selfadministered questionnaire. The data were processed and analyzed by software program SPSS version 20.0.

Results: More than half of genders were satisfied with availability of adequate academic and career counseling for students throughout the program. Also, the study materials in the courses are up to date and useful; the program had improved their skills in developing abilities, communication, knowledge and technology using. The results were not significant between genders.Sixth year students were more satisfied related to learning, agreed regarding study materials in the courses are up to date and useful. Also they were agreed about the availability of resources. The program has improved their abilities to work effectively in groups item.A significance difference were detected among gender in items \# 3 in support and among level of the subjects at items \#5.

Conclusion:Majority of the participants were satisfied with availability of adequate academic and career counseling for students throughout the program. Sixth year students were more satisfied related to learning and support. They agreed regarding study materials, availability of resources when they need them. The program has improved their abilities to work effectively in groups. These data can serve as a baseline for longitudinal quality assessments of $6^{\text {th }}$ year and graduated subjects at CMJU.
\end{abstract}

Keywords:program evaluation, final year medical students, graduated opinion, educational environment, college of medicine, Jazan University

\section{Introduction}

Saudi Arabia is a large country, occupies the major part of the Arabian Peninsula and has a population of approximately 24.5 million (1-2). Medical and dental care is provided largely by governmental institutions and, to a lesser extent, by private hospitals and clinics. The number of Saudi physicians is low and because of this, most of the medical practitioners in Saudi Arabia are non-Saudis from different parts of the world (3).

The medical colleges followed the same 6-year traditional curriculum, which consisted of 3 years of basic and medical science courses, 3 years of clinical training, followed by one year internship program, with minor differences between universities in the arrangement of disciplines and the subjects (2). The curriculum of the College of Medicine, Jazan University (CMJU) is an integrated system program which had three phases premed ( $1^{\text {st }}$ year $)$, Organ Systems $\left(2^{\text {nd }}, 3^{\text {rd }}\right.$ year $)$ and clinical clerkship $\left(4^{\text {th }}, 5^{\text {th }}, 6^{\text {th }}\right.$ year $)$ which followed by a one year of internship.

The final-year teaching program concentrates on the clinical perspectives of medical care and is conducted by way of a string of lectures and interactive case discussions on health in hospitals, relaying of health-related information, social responsibilities of doctors, and how aspects of the clinical impact the outcome of clinical management (4).

The medical curricula must be effective and relevant as they are of fundamental importance in the training of general practitionerdoctors (5), how effective or relevant they are may be a matter of perception (6). The weak implementation of curricula is known to result in unfavorable student perceptions (7). Furthermore, a positive perceptions are known to increase student motivation and, therefore, learning. Brooks, a constructivist, suggests that student opinion should be sought and valued (8). Thus, the frequent assessments of student perceptions are recommended and many agree that they are useful in the building of the curriculum,making them more acceptable and beneficial (9). 
At the end of 2005, the Council of Higher Education approved the establishment of the National Commission for Academic Assessment and Accreditation (NCAAA), which is an independent body, financially and administratively, reporting to the Council of Higher Education (2). Its responsibilities include establishing standards, criteria and procedures for accreditation, reviewing and evaluating performance of existing and new institutions, accrediting institutions and programs, and supporting improvements in quality $(10,11,12)$.

There are no reported studies that had evaluated the program curriculum. The Program Evaluation Survey (PES) is a survey organized by NCAAA to evaluate the final year and graduated doctors about their program. So the objective of this study was to evaluate the final year and graduated students about the quality of learning experiences at the College of Medicine, Jazan University. Also to compare between males and females from the same year. The learning experiences about their program were included; advice, help and support for learning; learning resources, facilities and teaching.

\section{Subjects And Methods}

This cross-sectional study was involved all the final year and the graduated subjects from both male and females, who were present in the main campus during the study period (April 2004). The subjects posted at other locations were excluded from the study. All participants in the study were informed about the objectives of the study, and the instrument used was explained by well-trained students who acted as research assistants. This study was conducted in College of Medicine, Jazan University (CMJU) at Jazan city. The city of Jazan is located in south-western part of Saudi Arabia between longitude 42 degrees 8, 43 degrees and attitudes 5, 16 degrees and 17 degrees. it's bounded to the north by Assir region and to the south by the state of Yemen and from the east Assir region and the state of Yemen, and the red sea to the west.

An ethical approval to conduct this study was obtained and approved from the Research and Ethics Committee at CMJUbefore starting distributions of the questionnaires and data collection.

A total of 66 subjects (41; male and 25; females) were included in this study. The questioners were distributed to students by their corresponding mails (online questioner) through the academic channels in the college. The questioner was included the consent for singeing by the participants. Convenience sampling method was used to enrolled final year and interns in the college.

The study was depending on the Program Evaluation Survey (PES), which is recommended by the National Commission for Academic Assessment and Accreditation. This survey is intended to be used at the time students have finished their program and or are about to graduate. It is recommended that distributed shortly before final year classes are finished so their opinion of the total program at that stage can be assessed. The questions include a number of items about the program itself together with some items deal with their life as a graduated at the institution, help, support and facilities for learning.

All the data were verified, arranged then entered into a Statistical Package for Social Sciences (SPSS) software program (version 20.1 SPSS, Chicago, Illinois, USA). Frequency distributions were obtained and descriptive statistics were calculated. Another level of data analysis was through calculating the means of the variables and Chi-square. The values of $\mathrm{P}$ Value $\mathrm{P}$ of $<0.05$ were considered as significant.

\section{Results}

A total number of 66 subjects; (males 41 (61\%) and 26 female (39\%) students had participated in the study. The highest number of the students were in the $6^{\text {th }}$ year $(56 ; 38.1 \%)$. Figure 1 , shows the distribution and percentage of the subjects.

Figure 1: distribution of the subjects according to the year and gender

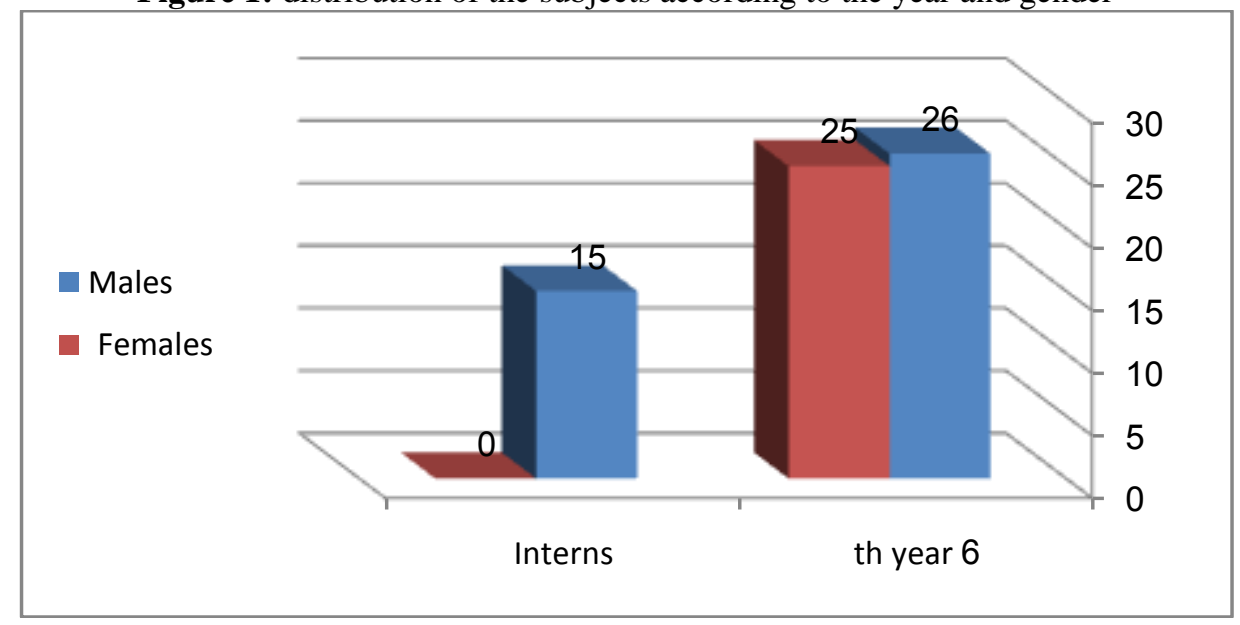


Opinions of Final Year and Interns about the Educational Environment and Medical...

Table 1: Response about help and support for learning according to gender:

\begin{tabular}{|c|c|c|c|c|}
\hline \multirow[t]{2}{*}{ Item (7 items) } & \multicolumn{3}{|c|}{ Positive response \% (n) } & \multirow[t]{2}{*}{$P$ value } \\
\hline & Total $(\mathrm{n}=66)$ & Male $(n=41)$ & Female $(n=25)$ & \\
\hline $\begin{array}{l}\text { 1) Availability of adequate academic and career } \\
\text { counseling for students throughout the program }\end{array}$ & $65.9 \%(27)$ & $44 \%(11)$ & $39.4 \%(38)$ & 0.221 \\
\hline $\begin{array}{l}\text { 2) Availability of instructors for consultation and advice } \\
\text { when students need to speak with them }\end{array}$ & $46.3 \%(19)$ & $44 \%(11)$ & $45.4 \%(30)$ & 0.762 \\
\hline $\begin{array}{l}\text { 3) Program 's instructors' inspiration of students to do } \\
\text { their best }\end{array}$ & $26.8 \%(11)$ & $36 \%(9)$ & $30.3 \%(20)$ & 0.356 \\
\hline $\begin{array}{l}\text { 4) Program's instructors give students help feedback on } \\
\text { their work. }\end{array}$ & $41.5 \%(17)$ & $40 \%(10)$ & $40.9 \%(27)$ & 0.446 \\
\hline $\begin{array}{l}\text { 5) Program's instructors have thorough knowledge of } \\
\text { the content of the course they teach }\end{array}$ & $48.8 \%(20)$ & $48 \%(12)$ & $48.5 \%(32)$ & 0.181 \\
\hline 6) Enthusiasm of the instructors about the program & $51.2 \%(21)$ & $52 \%(13)$ & $51.5 \%(34)$ & 0.090 \\
\hline $\begin{array}{l}\text { 7) Caring of instructors about the progress of their } \\
\text { students }\end{array}$ & $53.7 \%(22)$ & $52 \%(13)$ & $53 \%(35)$ & 0.586 \\
\hline
\end{tabular}

Table 1; shows the response about help and support for learning according to gender: Majority of the participants were satisfied with availability of adequate academic and career counseling for students throughout the program but only $26.8 \%$ of students have positive response to item (3). The results were not significant between genders.

Table 2: The responses about resources to support learning according to gender

\begin{tabular}{|l|l|l|l|l|}
\hline Item (7 items) & \multicolumn{2}{l}{ Positive response $\%$ value } \\
\cline { 2 - 4 } & Total $(\mathrm{n}=66)$ & Male (n=41) & Female (n=25) & \\
\hline 1) Study materials in the courses are up to date and useful & $61 \%(25)$ & $32 \%(8)$ & $50 \%(33)$ & 0.243 \\
\hline $\begin{array}{l}\text { 2) Adequacy and availability of library resources when } \\
\text { students need them }\end{array}$ & $58.5 \%(34)$ & $24 \%(6)$ & $45.21 \%(30)$ & $0.010^{*}$ \\
\hline 3) Classroom facilities are of good quality & $46.3 \%(19)$ & $32 \%(8)$ & $40.9 \%(27)$ & 0.551 \\
\hline $\begin{array}{l}\text { 4) Sufficiency of student computing facilities for students } \\
\text { needs }\end{array}$ & $41.4 \%(17)$ & $40 \%(10)$ & $40.9 \%(27)$ & 0.461 \\
\hline $\begin{array}{l}\text { 5) Availability of adequate facilities for extra-curricular } \\
\text { activities }\end{array}$ & $46.3 \%(19)$ & $28 \%(7)$ & $39.4 \%(26)$ & 0.105 \\
\hline $\begin{array}{l}\text { 6) Availability of adequate facilities for religious } \\
\text { observances }\end{array}$ & $48.8 \%(21)$ & $36 \%(9)$ & $44 \%(29)$ & 0.407 \\
\hline $\begin{array}{l}\text { 7) Effectiveness of field experience programs in developing } \\
\text { students skills. }\end{array}$ & $43.9 \%(18)$ & $40 \%(10)$ & $42.4 \%(28)$ & 0.809 \\
\hline
\end{tabular}

* Significance difference between genders

Table 2; shows the responses about the resources to support learning according to gender: A total of $61 \%$ of students found that the study materials in the courses are up to date and useful. Females were more agreed with item (2) which deled with the availability of library resources and it was significantly between the genders.

Table 3: The responses about evaluation of learning according to gender:

\begin{tabular}{|c|c|c|c|c|}
\hline \multirow{2}{*}{ Item (8 items) } & \multicolumn{3}{|c|}{ Positive response \% (n) } & \multirow{2}{*}{$P$ value } \\
\hline & Total $(n=66)$ & Male $(n=41)$ & Female $(n=25)$ & \\
\hline $\begin{array}{l}\text { 1) Volubility of what students have learned in this program } \\
\text { for their future. }\end{array}$ & $48.8 \%(20)$ & $56 \%(14)$ & $51.5 \%(34)$ & 0.801 \\
\hline $\begin{array}{l}\text { 2) Program's helpfulness of students to develop sufficient } \\
\text { interest to want to continue to keep up to date with new } \\
\text { developments in their field of study }\end{array}$ & $48.8 \%(20)$ & $40 \%(10)$ & $45.5 \%(21)$ & 0.270 \\
\hline $\begin{array}{l}\text { 3) Program has develop students" abilities to investigate } \\
\text { and solve new problems }\end{array}$ & $60 \%(25)$ & $44 \%(11)$ & $54.6 \%(36)$ & 0.133 \\
\hline $\begin{array}{l}\text { 4) Program has improve students abilities to work } \\
\text { effectively in groups }\end{array}$ & $58.8 \%(24)$ & $56 \%(14)$ & $57.5 \%(38)$ & 0.060 \\
\hline 5) Program has improve students‘ skills in communication & $68.3 \%(28)$ & $28 \%(7)$ & $53 \%(35)$ & $0.031 *$ \\
\hline $\begin{array}{l}\text { 6) Program's helpfulness of students to develop good basic } \\
\text { skills in using technology to investigate issues and } \\
\text { communicate results }\end{array}$ & $48.8 \%(20)$ & $28 \%(7)$ & $40.9 \%(27)$ & 0.322 \\
\hline $\begin{array}{l}\text { 7) Students ' development of the knowledge and skills } \\
\text { required for their chosen career }\end{array}$ & $51.2 \%(21)$ & $40 \%(10)$ & $47 \%(31)$ & 0.616 \\
\hline $\begin{array}{l}\text { 8) Overall students' satisfaction with the quality of their } \\
\text { learning experiences at this institution }\end{array}$ & $41.5 \%(17)$ & $25 \%(6)$ & $35.4 \%(23)$ & 0.207 \\
\hline
\end{tabular}

* Significance difference between genders

Table 3; shows the responses about evaluation of learning according to gender: Majority of students found that's the program has improved their skills in developing abilities, communication, knowledge and technology using. The females have more positive response than males regarding this item (5). 
Table 4: The response about help and support for learning according to year:

\begin{tabular}{|c|c|c|c|}
\hline \multirow[t]{2}{*}{ Item ( 7 items) } & \multicolumn{2}{|c|}{ Positive response \% (n) } & \multirow[t]{2}{*}{$P$ value } \\
\hline & $6^{\text {th }}$ year $(n=51)$ & Graduated $(\mathrm{n}=15)$ & \\
\hline $\begin{array}{l}\text { 1) Availability of adequate academic and career counseling } \\
\text { for students throughout the program }\end{array}$ & $56.9 \%(29)$ & $60 \%(9)$ & 0.453 \\
\hline $\begin{array}{l}\text { 2) Availability of instructors for consultation and advice } \\
\text { when students need to speak with them }\end{array}$ & $45.1 \%(23)$ & $46.7 \%(7)$ & 0.459 \\
\hline $\begin{array}{l}\text { 3) Program's instructors' inspiration of students to do their } \\
\text { best }\end{array}$ & $33.3 \%(17)$ & $20 \%(3)$ & 0.328 \\
\hline $\begin{array}{l}\text { 4) Program 's instructors give students help feedback on their } \\
\text { work }\end{array}$ & $41.2 \%(21)$ & $40 \%(6)$ & 0.510 \\
\hline $\begin{array}{l}\text { 5) Program's instructors have thorough knowledge of the } \\
\text { content of the course they teach }\end{array}$ & $52.9 \%(27)$ & $33.3 \%(5)$ & $0.034 *$ \\
\hline 6) Enthusiasm of the instructors about the program & $54.9 \%(28)$ & $40 \%(6)$ & 0.571 \\
\hline 7) Caring of instructors about the progress of their students & $49 \%(25)$ & $66.7 \%(10)$ & 0.147 \\
\hline
\end{tabular}

* Significance difference between different levels

Table 4; shows the response about help and support for learning according to year: $6^{\text {th }}$ year students are more satisfied than graduates about the instructor knowledge of their courses item (5) which may indicates improvement regarding this item.

Table 5: The responses about resources to support learning according to year:

\begin{tabular}{|c|c|c|c|}
\hline \multirow[t]{2}{*}{ Item (7 items) } & \multicolumn{2}{|c|}{ Positive response \% (n) } & \multirow[t]{2}{*}{$P$ Value } \\
\hline & $6^{\text {th }}$ year $(n=51)$ & Graduated $(n=15)$ & \\
\hline 1) Study materials in the courses are up to date and useful & $43.1 \%(22)$ & $73.4 \%(11)$ & $0.031 *$ \\
\hline $\begin{array}{l}\text { 2) Adequacy and availability of library resources when } \\
\text { students need them }\end{array}$ & $43.1 \%(22)$ & $53.3 \%(8)$ & $0.008 *$ \\
\hline 3) Classroom facilities are of good quality & $35.3 \%(18)$ & $60 \%(9)$ & 0.346 \\
\hline $\begin{array}{l}\text { 4) Sufficiency of student computing facilities for students } \\
\text { needs }\end{array}$ & $41.2 \%(21)$ & $40 \%(6)$ & 0.478 \\
\hline $\begin{array}{l}\text { 5) Availability of adequate facilities for extra-curricular } \\
\text { activities }\end{array}$ & $37.3 \%(19)$ & $46.7 \%(7)$ & 0.646 \\
\hline $\begin{array}{l}\text { 6) Availability of adequate facilities for religious } \\
\text { observances }\end{array}$ & $43.1 \%(22)$ & $46.7 \%(7)$ & 0.572 \\
\hline $\begin{array}{l}\text { 7) Effectiveness of field experience programs in developing } \\
\text { students skills }\end{array}$ & $41.2 \%(21)$ & $46.7 \%(7)$ & 0.050 \\
\hline
\end{tabular}

* Significance difference between different years

Table 5; illustrates the responses about resources to support learning accordingto year: Graduates weremore agreed regarding study materials in the courses are up to date and useful. Also they are agreed about the availability of resources when they need them. Items regarding the contents of the subjects are up-to date and the availability of resources at the library was significant differences between the subjects.

Table 6:The responses of evaluation of learning according to to year:

\begin{tabular}{|l|l|l|l|}
\hline \multirow{2}{*}{ Item (8 items) } & \multicolumn{2}{|l}{ Positive response \% (n) } \\
\cline { 2 - 3 } & $6^{\text {th }}$ year(n=51) & Graduated (n=15) \\
\hline $\begin{array}{l}\text { 1) Valuability of what students have learn in this program for their } \\
\text { future }\end{array}$ & $51 \%(26)$ & $53.3 \%(80$ & 0.467 \\
\hline $\begin{array}{l}\text { 2) Program's helpfulness of students to develop sufficient interest } \\
\text { to want to continue to keep up to date with new developments in } \\
\text { their field of study }\end{array}$ & $41.2 \%(21)$ & $66 \%(9)$ & 0.627 \\
\hline $\begin{array}{l}\text { 3) Program has develop students' abilities to investigate and solve } \\
\text { new problems }\end{array}$ & $52.9 \%(27)$ & $60 \%(9)$ & 0.221 \\
\hline $\begin{array}{l}\text { 4) Program has improvedstudents 'abilities to work effectively in } \\
\text { groups. }\end{array}$ & $58.8 \%(30)$ & $53.4 \%(8)$ & $0.003^{*}$ \\
\hline 5) Program has improve students' skills in communication & $53 \%(27)$ & $53.4 \%(8)$ & 0.398 \\
\hline $\begin{array}{l}\text { 6) Program's helpfulness of students to develop good basic skills } \\
\text { in using technology to investigate issues and communicate results }\end{array}$ & $43.1 \%(22)$ & $33.4 \%(5)$ & 0.527 \\
\hline $\begin{array}{l}\text { 7) Students' development of the knowledge and skills required for } \\
\text { their chosen career }\end{array}$ & $49 \%(25)$ & $40 \%(6)$ & 0.685 \\
\hline $\begin{array}{l}\text { 8) Overall students 'satisfaction with the quality of their learning } \\
\text { experiences at this institution. }\end{array}$ & $40 \%(20)$ & $20 \%(3)$ & 0.229 \\
\hline
\end{tabular}

* Significance difference between different years

Table 6; shows the positive responses about evaluation of learning according to to year: Sixth year students were more satisfied related to learning. The program has improved their abilities to work effectively in groups item (4). 


\section{Discussion}

The above, well-implemented curricula are received positively by graduated and are more likely to facilitate learning. The method that we used to assess graduated satisfaction with the curriculum was measurement by the quality of the Program Experience Survey. It may be argued that graduated perceptions of various aspects of the courses are interdependent, and therefore, cannot be considered in isolation or that students who view a certain area of the curriculum positively are more likely to view others in a similar manner due to characteristics of their personality. While this may be true, it does not detract from the evidence that perceptions influence learning, whatever their basis may be. It is clear that perceptions alone may be inadequate in aiding assessment as they are subjective and liable to be affected by various situations and variables. However, when combined with an additional objective measure it holds great value (13).

The curriculum of CMJU provides active methods of instruction that include: small group discussion, tutorials, problem-based learning, case-study, clinical presentations, skills practice, seminars, practical, demonstration, and student independent learning. Methods of evaluating students include continuous and summative assessment; mid and final term exams as well as quizzes.

The objective of this cross sectional study was to evaluate the final year and graduated interns about the quality of learning experiences at the College of Medicine, Jazan University. Also to compare between males and females from the same year. The learning experiences about their program were included; advice, help and support for learning; learning resources, facilities and teaching using Program Evaluation Survey (PES).

In Program Experience Survey we found that overall 6th year and intern's satisfaction about help and support for learning regarding NCAAA system, which indicates good performance. Males have high quality performance about availability of adequate academic and career counseling for students throughout the program. Care of instructors about the progress of their students while females have good performance regarding the same two items $(1,10-12)$.

Our results in tables (1-3) shows help, support for learning surfaces according to gender shows that, majority of students from male and females were satisfied with the supports, this is in agreements with $\mathrm{Al}$ Rabaish A(14) Dammam University, karim et al 2015 (15) Kuwait University, Imran et al (16) at Rabigh and Jeddah campuses of King Abdulaziz University, BHCSALE J (17), Al-Mohaimeed A (18) Medical College at Qassim University, Al-Ayedand Sheik (19) at King Saud University.

Overall students' satisfaction about resources to support learning regarding NCAAA system which indicates good performance. And about the satisfaction about evaluation of learning regarding NCAAA system, which also indicates good performance. Program has developedstudents 'abilities to investigate and solve new problems. Program has improve students 'abilities to work effectively in groups and has improve students ' skills in communication were indicated high quality performance among males than female. This is in Al Mohaimeed et al (12), Rahman et al (20) at Sultan ZainalAbidin Medical College, Malyzia, Al-hazmi et al (21) King Abdul Aziz University at Jeddah KSA.

The results showed no significant different between gender, which was not agreed with the results founded at Sultan ZainalAbidin Medical College, Malyzia by Rahman et al (20) and at Sharjah Medical College, United Arab of Emirates by Nosair et al (22). This differences could be explained by the sample size. In our study only male internes were involved. The only significant were item \# 2 (table 2, and \# 5 table \# 3), which deal with adequacy and availability of library resources when students need them program has improve students' skills in communication respectively. This were obvious in the results of $(15,21,22,24)$

The response about help and support for learning according to year, resources to support learning according to year (table 4 and 5). The $6^{\text {th }}$ year students are more satisfied than graduates about the instructor knowledge of their courses item (5) Which may indicates improvement regarding this item. Similar results were mentioned by karim et al 2015 (15) Kuwait University, Al-Mohaimeed A (18) Medical College at Qassim University, Al-Ayedand Sheik (19) at King Saud University.

Significant of the study materials and adequacy and availability of library resources, this was in agreements with the results of $16,17,19,21,22,23,24$. Those demonstrated that graduated founded the needed material at the library each time they needed.

Finally from table 6 , there was significant differences between $6^{\text {th }}$ year and internes in the item \#4, which was regarding improvement the ability to work as a group, this is strongly agreed with Al Mohaimeed et al (12), Rahman et al (20) at Sultan ZainalAbidin Medical College, Malyzia, Al-hazmi et al (21) King Abdul Aziz University at Jeddah KSA.

The limitation of this study is the nature of self-reporting of questionnaires imposed some limitation to the conclusions of this study. The validity and accuracy of student perceptions of their learning and learning environments has been questionable. Also the considered academic program involves a comparatively small number of students at interns. 


\section{Conclusion}

The following conclusions were drowning from this cross sectional study for 6th year and interns subjects. According to gender regarding help, support and learning, majority of the participants were satisfied with availability of adequate academic and career counseling for students throughout the program. The study materials in the courses were up to date and useful;also, the program had improved their skills in developing abilities, communication, knowledge and technology using. The results were not significant among genders. 6th year students were more satisfied related to learning. They were agreedthat study materials in the courses were up to date and useful, and the availability of resources when they need them. The program has improved their abilities to work effectively in group's item.

\section{References}

[1]. Telmesani A, Zaini RG, Ghazi. OH. Medical education in Saudi Arabia: a review of recent developments and future challenges. E M H J $2011 ; 17: 703-7$.

[2]. Health statistic book for the year of 2006, Riyadh, Saudi Arabia, Ministry of Health, 2006.

[3]. Al-Shamrani SM. Evaluation of the unified pre-health sciences program by dental students and interns in the College of Dentistry, King Saud University, Riyadh, Saudi Arabia. S Dent J 2002; 14: 3-6.

[4]. Navinan MR, Wijayaratne DR, Rajapakse S. Final-Year Medical Students' Perceptions Regarding the Curriculum in Public Health. Indian J Comm Med 2011; 36(4): 268-274.

[5]. Alam A. How do medical students in their clinical years perceive basic science courses at King Saud University. Ann Saudi Med. 2011;31:58-61.

[6]. D'Eon MF. Knowledge loss of medical students on first year basic science course at the University of Saskatchewan. BMC Med Educ. 2006;6:5.

[7]. Lazić E, Dujmović J, Hren D. Retention of basic sciences knowledge at clinical years of medical curriculum. Croat Med J. 2006;47:882-7.

[8]. Al-Gindan YM, Al-Sulaiman AA, Al-Faraidy A. Undergraduate Curriculum reform in Saudi Medical Schools. Which direction to go. Saudi Med J. 2000;21:324-6.

[9]. Alsheri MY. Medical curricula in Saudi medical colleges: current and future perspectives. Ann Saudi Med2001;21:320-3.

[10]. Darandari E. etal. The Quality Assurance System for Post-Secondary Education in Saudi Arabia: A Comprehensive, Developmental and Unified Approach. Quality in Higher Education. 2009. 15(1): 39 - 50.

[11]. Al-Musallam A. Higher Education Accreditation and Quality Assurance in the Kingdom of Saudi Arabia. Paper presented at the First National conference for Quality in Higher Education; 2007 May 15-16; Riyadh, Saudi Arabia.

[12]. 12- Al Mohaimeed AR, Midhet F, Barrimah I, Saleh M N-El-Din. Academic Accreditation Process: Experience of a Medical College in Saudi Arabia. Int J Health Sciences 2012: 6: 13-9.

[13]. Imperato PJ, Feldman J, Nayeri K. Second year medical student opinion about public health and a second year course in preventive medicine and community health. J Community Health. 1986;11:244-58.

[14]. Al Rabaish A, The Use of Global student rating itmes under end program evaluation survey in Quality Improvments: An Institutional Experience in Higher Eduction, Saudi Arabia.iBusiness 2012; 4 : 1-9.

[15]. Karim J, Al-Halabi B, Marwan Y, Sadeq H, Dawas A, Al-Abdulrazzaq D. The educational environment of the undergraduate medical curriculum at Kuwait University. Adv Med EducPract 2015: 6: 297-303.

[16]. Imran M, Shamim MS, Baig M, Farouq M, Gazzaz ZJ, Al-Mutairi OM. Tale of two cities: comparison of educational environment of two colleges (Jeddah and Rabigh) affiliated with one university. JPMA 2016; 66: 316- 19.

[17]. BHOSALE U. Medical Students' Perception about the Educational Environment in Western Maharashtra in Medical College using DREEM Scale. JCDR 2015; 9: 1-4.

[18]. Al-Mohaimeed A. Perceptions of the educational environment of a new medical school, Saudi Arabia. Internl J Health Sciences 2013; 7: 150-9.

[19]. Al-Ayed IH, Sheik SA. Assessment of the educational environment at the College of Medicine of King Saud University, Riyadh. E M H J 2008; 14: 953- 9.

[20]. Rahman NIA, Abd Aziz A, Zulkifli Z, et al. Perceptions of students in different phases of medical education of the educational environment: Universiti Sultan ZainalAbidin. Advances in Medical Education and Practice 2015: 6: 210-21.

[21]. Awdah Al-hazimi. Perception of educational environment of the medical school in king abdulaziz university, Saudi Arabia. Medical Teacher 2004; 26(6): 570-573

[22]. Nosair E, Mirghani Z, Mostafa RM. Measuring Students' Perceptions of Educational Environment in the PBL Program of Sharjah Medical College. J MedlEduca\&CurricuDevelo 2015; 2: 71-9.

[23]. Park et al. Student perception of the educational environment of medical shool in Korea: finding from a national survy. K J M E 2015; 27: 117-30.

[24]. Bouhaimed M, Thalib L, Suhail A.R. Perception of the Educational Environment by Medical Students Undergoing a Curricular Transition in Kuwait. Med PrincPract 2009;18:204-8. 